\title{
Biosorption of lead, chromium and cadmium in tannery effluent using indigenous microorganisms
}

\author{
O. P. Abioye ${ }^{1, *}$, O. A. Oyewole ${ }^{1}$, S. B. Oyeleke ${ }^{1}$, M. O. Adeyemi ${ }^{1}$ and \\ A. A. Orukotan ${ }^{2}$ \\ ${ }^{1}$ Department of Microbiology. Federal University of Technology Minna. Nigeria. \\ *Email: bisyem2603@yahoo.com. \\ ${ }^{2}$ Department of Microbiology. Kaduna State University. Kaduna. Nigeria.
}

\begin{abstract}
This study investigated the biosorption of lead, chromium and cadmium in tannery effluent using indigenous microorganisms. Bacteria isolated from the tannery effluent were Bacillus subtilis and B. megaterium while fungi isolated were Aspergillus niger and Penicillium sp. The microorganisms were tested for their ability to reduce the concentration of the heavy metals in the tannery effluent using conventional methods. B. megaterium recorded the highest lead reduction ( 2.13 to $0.03 \mathrm{mg} / \mathrm{L})$, followed by B. subtilis $(2.13-0.04 \mathrm{mg} / \mathrm{L})$. A. niger recorded the highest ability to reduce the concentration of chromium (1.38-0.08 mg/L) followed by Penicillium sp. $(1.38-0.13 \mathrm{mg} / \mathrm{L})$ while $B$. subtilis exhibited the highest ability to reduce the concentration of cadmium (0.4-0.03 mg/L) followed by $B$. megaterium $(0.04-0.06 \mathrm{mg} / \mathrm{L})$ after 20 days. When these values were compared to standard limits of Federal Environmental Protection Agency (FEPA), World Health Organization (WHO), National Environmental Standard and Regulations Enforcement Agency (NESREA) and Central Pollution Control Board (CPCB), the isolates recorded an acceptable reduction in the concentration of lead, chromium and cadmium in sterile and unsterile tannery effluent. The results of this showed that the isolates reduced the concentration of lead, chromium and cadmium present in the sterile and raw tannery effluent and suggest that the organisms can be used as a possible treatment of tannery effluents.
\end{abstract}

Keywords: Tannery effluent; Lead; Chromium; Cadmium; Biosorption; Bacteria; Fungi.
Received

March 09, 2018

Accepted

April 23, 2018

Released

April 30, 2018

Full Text Article

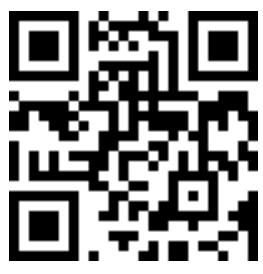

ORCID

(ㄱ) 0000-0001-7728-3115 O. P. Abioye

(ㄷ) 0000-0001-9470-8488 O. A. Oyewole

(1) 0000-0002-7778-1445 S. B. Oyeleke

(1) 0000-0002-5124-2275 M. O. Adeyemi

(1) 0000-0002-0833-5652 A. A. Orukotan

\section{Introduction}

Industrial effluents such as tannery effluent contains a high amount of metals especially chromium, copper, iron, zinc, mercury and cadmium (Malarkodi et al., 2007; Devi et al., 2011). Leather industries and tanneries 
generate massive by-products, solid wastes, high amount of wastewater rich in organic wastes different load of pollutants and emissions into the air. These effluents are released onto the land as well as into the surface water, which eventually reach the level of ground water and lead to contamination due to accumulation of toxic metallic components. This results into a series of problems when consumed, because they are partially or cannot be completely degraded (Malarkodi et al., 2007). The effluents contain several types of chemical such as dispersants, levelling agents, acids, alkalis, various dyes, phenols, carbonates, alcohols, cyanides and heavy metals (Noorjahan, 2014).

Effluents from raw hide processing tanneries contain components of chromium and sulphides in most cases with a major proportion of dyes (Noorjahan, 2014). Majority of tanneries worldwide use chromium ( $\mathrm{Cr}$ III and Cr IV), which are highly toxic and poses a serious threat to the environment upon improper disposal of their waste water. Even at low concentrations, these salts have a toxic effect on the food chain of fish and inhibits photosynthesis of aquatic plants (Bosnic et al., 2000). Bello et al. (2016) reported heavy metal accumulations in vital human organs via the consumption of crops after the discharge of tannery effluents for irrigation purpose. This results into various degrees of illnesses on acute and chronic exposure, such as cancer, kidney dysfunction, cholera and skin irritations (Mustafa et al., 2010). Heavy metals in the tannery effluent is one of the most hazardous environmental pollutants, toxic heavy metals like $\mathrm{Cr}, \mathrm{Cu}, \mathrm{Zn}, \mathrm{Pb}$ and $\mathrm{Cd}$ are mostly absorbed and get accumulated in various plant part as free metals, which may adversely affect the plant growth and metabolism. Major diseases of cattle and human beings are caused by chromium and nickel and cancer (Sivakumar and Thippeswamy, 2012).
The conventional treatment of tannery effluents for the purpose of detoxification requires application of physical and chemical methods, which involve the chrome precipitation and sulphide treatment including physicochemical methods such as filtration, specific coagulation, use of activated carbon and chemical flocculation (Olukanni et al., 2006). But due to associated problems in these treatment methods such as high cost, intense experimental set-up, in complete treatment of wastewater leading to posttreatment effects (Do et al., 2002; Maier et al., 2004), other alternative treatment methods have been researched such as the use of biological methods using bacteria, fungi and algae (Srinivas and Estari, 2013).

Therefore, the aim of this study was to utilise bacteria and fungi isolated from tannery effluent for the biosorption of $\mathrm{Cr}, \mathrm{Pb}$ and $\mathrm{Cd}$ in tannery effluent.

\section{Materials and methods}

\section{Sample collection \\ The tannery}

effluent contaminated soil and tannery effluent samples were collected from the Leather Processing Industry Site in Zaria, Nigeria, in sterile different containers and were transported to the Microbiology Laboratory of the Federal University of Technology Minna, Nigeria, for microbiological and physiochemical analysis.

\section{Isolation of microorganisms}

One gram of tannery effluent contaminated soil sample was serially diluted with $9 \mathrm{~mL}$ of sterile water. The $0.1 \mathrm{~mL}$ of the diluted soil sample was plated on Nutrient Agar (for bacteria) and Sabouraud Dextrose Agar (for fungi) using pour plate method of isolation. The plates were incubated at $37{ }^{\circ} \mathrm{C}$ for $24 \mathrm{~h}$ (for bacteria) while for fungi, the plates were incubated at $28 \pm 2{ }^{\circ} \mathrm{C}$ for 4 days. 


\section{isolates \\ Identification of bacterial}

Each colony that differ in size, shape and colour were subcultured to obtain pure isolates. The bacteria isolated were identified based on the colonial, microscopic and biochemical characteristics. The following biochemical tests were used: Gram staining, motility, indole production, methyl red, Voges Proskauer, citrate utilization, production of oxidase, catalase, coagulase, and urease, sugar fermentation test, spore staining, nitrate reduction test and starch hydrolysis (Cheesbrough, 2006). The bacterial isolates were identified by comparing their characteristics with those of known taxa (Holts et al., 1994).

\section{Identification of fungi isolates}

Fungi identification was based on the morphological and microscopic examination of each isolate. Morphological examination included colonial and colour while microscopic examination involved staining with lactophenol cotton blue and viewed using $\mathrm{x} 10$ and $\mathrm{x} 40$ objective lens. The fungal isolates were identified by comparing their characteristics with those of known taxa (Domsch and Gams, 1970).

\section{solutions}

Preparation of heavy metal

The stock solution of chromium was prepared by dissolving $0.002 \mathrm{~g}$ of potassium dichromate in $500 \mathrm{~mL}$ of distilled water. To obtain $1.5 \mathrm{ppm}$, the solution was shaken for 15 minutes and allowed to stand for $24 \mathrm{~h}$. The stock solution of lead was prepared by dissolving $0.0015 \mathrm{~g}$ of lead acetate in 500 $\mathrm{mL}$ of distilled water to obtain $1.5 \mathrm{ppm}$. The stock solutions of cadmium was prepared by dissolving $0.0017 \mathrm{~g}$ of cadmium sulphate in $500 \mathrm{~mL}$ of distilled water to obtain $1.5 \mathrm{ppm}$. To obtain 1.0 ppm, $167 \mathrm{~mL}$ from each stock solutions was measured into $250 \mathrm{~mL}$ volumetric flask, and then distilled water was added to make it to $250 \mathrm{~mL}$, while the concentration of $0.5 \mathrm{ppm}, 50 \mathrm{~mL}$ from $250 \mathrm{~mL}$ (1.0 ppm concentration) was measured into $100 \mathrm{~mL}$ volumetric flask and distilled water was added to make I to $100 \mathrm{~mL}$ (Knopka and Zakharova, 1999).

Screening of the isolates for the potential to utilise heavy metals

The different concentrations $(1.5$ ppm, $1.0 \mathrm{ppm}$ and $0.5 \mathrm{ppm}$ in $500 \mathrm{~mL}$, $250 \mathrm{~mL}$, and $100 \mathrm{~mL}$ ) of each heavy metal (chromium, lead and cadmium) were prepared using the agar dilution method, with nutrient agar for bacteria and Sabouraud dextrose agar for fungi (Jayanthi et al., 2014). The media were sterilised using autoclave at $121^{\circ} \mathrm{C}$ for 15 min. After sterilisation, each was poured into Petri dish. The test organisms were inoculated using streak plate technique and incubated at $37^{\circ} \mathrm{C}$ (bacteria) and $28 \pm 2{ }^{\circ} \mathrm{C}$ (fungi) for $72 \mathrm{~h}$. Development of bacterial and fungal colonies indicate the ability of the isolates to tolerate the heavy metal while absence of visible colonies indicates that the test organisms cannot tolerate the heavy metals.

\section{Determination of $\mathrm{Pb}, \mathrm{Cr}$ and $\mathrm{Cd}$ in tannery effluent}

The $1 \mathrm{~L}$ of potatoes dextrose broth was prepared by boiling $300 \mathrm{~g}$ of fresh potatoes at $100^{\circ} \mathrm{C}$ in $500 \mathrm{~mL}$ of tannery effluent in a beaker. The potatoes were removed and the beaker was filled with tannery effluent to make up $1 \mathrm{~L}$. The $20 \mathrm{~g}$ of glucose and $0.4 \mathrm{~g}$ of chloramphenicol were added (for fungi). For the preparation of nutrient broth medium, $15 \mathrm{~g}$ of nutrient broth was dissolved in $1 \mathrm{~L}$ of tannery effluent (for bacteria).

The $50 \mathrm{~mL}$ of each medium was dispensed into 56 of $100 \mathrm{~mL}$ conical flask. The 24 of the flasks were sterilised while the other 24 were not sterilised and 8 of the conical flasks were used as control (no microorganism). The $1 \mathrm{~mL}$ of $3 \mathrm{~h}$ old culture of each isolate (in 
triplicate) was inoculated into the 24 flask.

The inoculated flasks were incubated aerobically in an incubator shaker at $37^{\circ} \mathrm{C}$, while the fungi were incubated at $28 \pm 2{ }^{\circ} \mathrm{C}$ (Deivasgamani and Das, 2011) for 20 days. Samples were removed at 5 days interval and centrifuged at $1200 \mathrm{rpm}$ for $15 \mathrm{~min}$ to separate the residue from supernatant. The supernatant was dispensed into clean sterile container and analysed to determine the level of $\mathrm{Pb}, \mathrm{Cr}$ and $\mathrm{Cd}$ using AAS.

\section{Statistical analysis}

Analysis of variance was used to determine significant difference between means, using SPSS version 16.0 and one tailed paired student's t-test was used to determine statistical significance between the untreated and treated parameters.

\section{Results}

The bacteria isolated from the tannery effluents were identified as
Bacillus subtilis, B. megaterium while the fungi isolates were identified as Aspergillus niger and Penicillium sp. (Table 1). There was a significant reduction in lead concentration in sterile effluents by the isolates when compared with day 0 throughout the period of 20 days. A. niger that showed a significant increase in lead concentration at day 5. $B$. megaterium recorded the highest lead reduction ( 2.13 to $0.03 \mathrm{mg} / \mathrm{L})$, followed by $B$. subtilis (2.13-0.04 mg/L), A. niger (2.13-0.1 $\mathrm{mg} / \mathrm{L})$ and Penicillium sp. (2.13-0.14 mg/L) after 20 days (Table 1 ). A. niger recorded the highest ability to reduce the concentration of chromium (1.38-0.08 $\mathrm{mg} / \mathrm{L})$, followed by Penicillium sp. $(1.38-0.13 \mathrm{mg} / \mathrm{L}), \quad B$. megaterium (1.38-0.20 mg/L) and the least was $B$. subtilis $(1.38-0.23 \mathrm{mg} / \mathrm{L})$ (Table 2). B. subtilis exhibited the highest ability to reduce the concentration of cadmium $(0.4-0.03 \mathrm{mg} / \mathrm{L})$ followed by $B$. megaterium (0.04-0.06 mg/L), A. niger (0.4-0.08 $\mathrm{mg} / \mathrm{L})$ and Penicillium had the least (0.4-0.1 mg/L) (Table 3).

Table 1. Microorganisms isolated from the effluent and their ability to uptake $\mathrm{Pb}$ in sterile tannery effluent.

\begin{tabular}{lcccc} 
Time (days) & Bacillus subtilis & B. megaterium & Aspergillus niger & Penicillium sp. \\
\hline 0 & $2.13 \pm 0.10^{\mathrm{a}}$ & $2.13 \pm 0.10^{\mathrm{a}}$ & $2.13 \pm 0.04^{\mathrm{a}}$ & $2.13 \pm 0.04^{\mathrm{a}}$ \\
5 & $2.00 \pm 0.00^{\mathrm{b}}$ & $1.30 \pm 0.005^{\mathrm{b}}$ & $2.41 \pm 0.02^{\mathrm{a}}$ & $1.56 \pm 0.04^{\mathrm{b}}$ \\
10 & $1.32 \pm 0.005^{\mathrm{c}}$ & $1.17 \pm 0.01^{\mathrm{c}}$ & $1.37 \pm 0.03^{\mathrm{b}}$ & $1.24 \pm 0.01^{\mathrm{c}}$ \\
15 & $0.09 \pm 0.00^{\mathrm{d}}$ & $0.06 \pm 0.051^{\mathrm{d}}$ & $0.47 \pm 0.02^{\mathrm{c}}$ & $0.47 \pm 0.02^{\mathrm{d}}$ \\
20 & $0.04 \pm 0.01^{\mathrm{c}}$ & $0.03 \pm 0.005^{\mathrm{e}}$ & $0.01 \pm 0.003^{\mathrm{d}}$ & $0.14 \pm 0.001^{\mathrm{e}}$ \\
\hline
\end{tabular}

Values are mean \pm standard error of mean of triplicate determination. Values with different letters down the row are significantly different $(\mathrm{p}<0.05)$. Concentration $(\mathrm{mg} / \mathrm{mL})$.

Table 2. Microorganisms isolated from the effluent and their ability to uptake Cr in sterile tannery effluent.

\begin{tabular}{lcccc} 
Time (Days) & Bacillus subtilis & B. megaterium & Aspergillus niger & Penicillium sp. \\
\hline 0 & $1.38 \pm 0.00^{\mathrm{a}}$ & $1.38 \pm 0.00^{\mathrm{a}}$ & $1.38 \pm 0.00^{\mathrm{a}}$ & $1.38 \pm 0.00^{\mathrm{a}}$ \\
5 & $1.16 \pm 0.015^{\mathrm{b}}$ & $1.25 \pm 0.003^{\mathrm{b}}$ & $1.06 \pm 0.002^{\mathrm{b}}$ & $1.07 \pm 0.006^{\mathrm{b}}$ \\
10 & $1.03 \pm 0.005^{\mathrm{c}}$ & $1.02 \pm 0.01^{\mathrm{c}}$ & $0.91 \pm 0.01^{\mathrm{c}}$ & $0.86 \pm 0.07^{\mathrm{c}}$ \\
15 & $0.84 \pm 0.01^{\mathrm{d}}$ & $0.86 \pm 0.005^{\mathrm{d}}$ & $0.38 \pm 0.006^{\mathrm{d}}$ & $0.44 \pm 0.004^{\mathrm{d}}$ \\
20 & $0.23 \pm 0.005^{\mathrm{e}}$ & $0.20 \pm 0.005^{\mathrm{e}}$ & $0.08 \pm 0.003^{\mathrm{e}}$ & $0.13 \pm 0.005^{\mathrm{e}}$ \\
\hline
\end{tabular}

Values are mean \pm standard error of mean of triplicate determination. Values with different letters down the row are significantly different $(\mathrm{p}<0.05)$. Concentration $(\mathrm{mg} / \mathrm{mL})$. 
Table 3. Microorganisms isolated from the effluent and their ability to uptake Cd in sterile tannery effluent.

\begin{tabular}{lcccc} 
Time (Days) & Bacillus subtilis & B. megaterium & Aspergillus niger & Penicillium sp. \\
\hline 0 & $0.40 \pm 0.00^{\mathrm{a}}$ & $0.40 \pm 0.00^{\mathrm{a}}$ & $0.40 \pm 0.00^{\mathrm{a}}$ & $0.40 \pm 0.00^{\mathrm{a}}$ \\
5 & $0.24 \pm 0.02^{\mathrm{b}}$ & $0.24 \pm 0.02^{\mathrm{b}}$ & $0.31 \pm 0.02^{\mathrm{b}}$ & $0.44 \pm 0.01^{\mathrm{b}}$ \\
10 & $0.21 \pm 0.00^{\mathrm{c}}$ & $0.18 \pm 0.005^{\mathrm{c}}$ & $0.28 \pm 0.005^{\mathrm{c}}$ & $0.36 \pm 0.004^{\mathrm{d}}$ \\
15 & $0.095 \pm 0.01^{\mathrm{d}}$ & $0.12 \pm 0.005^{\mathrm{d}}$ & $0.18 \pm 0.001^{\mathrm{d}}$ & $0.27 \pm 0.002^{\mathrm{c}}$ \\
20 & $0.03 \pm 0.005^{\mathrm{e}}$ & $0.06 \pm 0.00^{\mathrm{e}}$ & $0.08 \pm 0.01^{\mathrm{e}}$ & $0.10 \pm 0.02^{\mathrm{b}}$ \\
\hline
\end{tabular}

Values are mean \pm standard error of mean of triplicate determination. Values with different letters down the row are significantly different $(\mathrm{p}<0.05)$.

When these values were compared to standard limits of Federal Environmental Protection Agency, World Health Organization, National Environmental Standard and Regulations Enforcement Agency and Central
Pollution Control Board, the isolates recorded an acceptable reduction in the concentration of lead, chromium and cadmium in sterile (Table 4) and unsterile tannery effluent (Table 5) after 20 days.

Table 4. The presence of heavy metals in sterile tannery effluents treated with the isolates compared with standard limits after 20 days.

\begin{tabular}{lccccccccc}
\hline $\begin{array}{l}\text { Concentration } \\
(\mathbf{m g} / \mathbf{m L})\end{array}$ & $\begin{array}{c}\text { Initial } \\
\text { value }\end{array}$ & $\begin{array}{c}\text { B. } \\
\text { subtilis }\end{array}$ & $\begin{array}{c}\text { B. } \\
\text { megaterium }\end{array}$ & $\begin{array}{c}\text { A. } \\
\text { niger }\end{array}$ & $\begin{array}{c}\text { Penicillium } \\
\mathbf{s p} .\end{array}$ & $\begin{array}{c}\text { FEPA Limits } \\
(\mathbf{m g} / \mathbf{m L})\end{array}$ & $\begin{array}{c}\text { Who } \\
\text { limits } \\
(\mathbf{m g} / \mathbf{m L})\end{array}$ & $\begin{array}{c}\text { NESREA } \\
\text { Limits } \\
(\mathbf{m g} / \mathbf{m L})\end{array}$ & $\begin{array}{c}\text { CPCB } \\
\text { Limits } \\
(\mathbf{m g} / \mathbf{m L})\end{array}$ \\
\hline $\mathrm{Pb}$ & 2.13 & 0.04 & 0.03 & 0.10 & 0.14 & $<1.00$ & 1.00 & 0.1 & 0.1 \\
$\mathrm{Cd}$ & 0.44 & 0.03 & 0.06 & 0.08 & 0.10 & - & - & $0.1-0.4$ \\
$\mathrm{Cr}$ & 1.38 & 0.23 & 0.20 & 0.08 & 0.13 & $<1.00$ & 1.00 & $0.1-0.5$ & 0.1 \\
\hline
\end{tabular}

FEPA: Federal Environmental Protection Agency, WHO: World Health Organization, NESREA: National Environmental Standard and Regulations Enforcement Agency, CPCB: Central Pollution Control Board, -: No fixed standard.

Table 5. The presence of heavy metals in sterile tannery effluents treated with the isolates compared with standard limits after 20 days.

\begin{tabular}{|c|c|c|c|c|c|c|c|c|c|}
\hline $\begin{array}{l}\text { Concentration } \\
(\mathrm{mg} / \mathrm{mL})\end{array}$ & $\begin{array}{l}\text { Initial } \\
\text { value }\end{array}$ & $\begin{array}{c}\text { B. } \\
\text { subtilis }\end{array}$ & $\begin{array}{c}B . \\
\text { megaterium }\end{array}$ & $\begin{array}{c}\text { A. } \\
\text { niger }\end{array}$ & $\begin{array}{l}\text { Penicillium } \\
\text { sp. }\end{array}$ & $\begin{array}{l}\text { FEPA Limits } \\
(\mathrm{mg} / \mathrm{mL})\end{array}$ & $\begin{array}{l}\text { Who } \\
\text { limits } \\
(\mathrm{mg} / \mathrm{mL})\end{array}$ & $\begin{array}{l}\text { NESREA } \\
\text { Limits } \\
(\mathrm{mg} / \mathrm{mL})\end{array}$ & $\begin{array}{c}\text { CPCB } \\
\text { Limits } \\
(\mathrm{mg} / \mathrm{mL})\end{array}$ \\
\hline $\mathrm{Pb}$ & 1.38 & 1.12 & 0.21 & 0.50 & 0.42 & $<1.00$ & 1.00 & 0.1 & 0.1 \\
\hline $\mathrm{Cd}$ & 0.33 & 0.18 & 0.15 & 0.16 & 0.20 & - & - & $0.1-0.4$ & 2.0 \\
\hline $\mathrm{Cr}$ & 1.65 & 0.65 & 0.91 & 0.22 & 0.22 & $<1.00$ & 1.00 & $0.1-0.5$ & 0.1 \\
\hline
\end{tabular}

FEPA: Federal Environmental Protection Agency, WHO: World Health Organization, NESREA: National Environmental Standard and Regulations Enforcement Agency, CPCB: Central Pollution Control Board, -: No fixed standard.

\section{Discussion}

The soil is a suitable habitat for microorganism and most bacteria and fungi are indigenous to soil, but only four isolates were obtained from the tannery effluent and the soil sample. This indicates that it is only these organisms that are able to utilize the effluent for their growth and metabolism. The presence of microorganisms in tannery effluent soil may be as a result of their 
ability to utilize the compounds in the effluent samples or its soil. Their abundance and diversity may be attributed to high tanning activities and destabilization of soil ecological balance arising from the contaminations due to the discharge of the tannery waste water (Rabah and Ibrahim, 2010).

Generally, bacteria and fungi have developed various processed such as transport across to cell membrane, biosorption to cell was, entrapments in extracellular capsules, precipitation, complexation and oxidation-reduction reactions They have proven to take up heavy metals from aqueous solutions, especially when the metal concentrations in the effluent range from less than 1 $\mathrm{mg} / \mathrm{L}$ to about $20 \mathrm{mg} / \mathrm{L}$ (Salman et al., 2014).

According to Meenambigail et al. (2016), microorganisms a play a vital role in bioremediation of heavy metals from contaminated soil and wastewater, but when microorganisms are exposed to higher concentration of heavy metals, it may have a deleterious effects on their growth and activities. Bacteria isolated included Bacillus subtilis and B. megaterium (Table 1). This is similar to the report of Bello et al. (2016) who reported the presence of Bacillus species in soil contaminated with industrial wastewater due to their ability to survive in extreme conditions such as heat, chemical and desiccation due to the spores. In addition, Bacillus sp. Have the ability to secrete hydrolytic enzymes capable of degrading heavy metals. Abioye et al. (2015) reported that the presence of techoic acid in B. subtilis (a Gram positive bacterium) may also be an added advantage because tit serves as a source of carboxyl groups that are the main agents in heavy metal uptake. $B$. subtilis. The presence of iron chelating siderophores enable them to be used in metal pollution (León et al., 2009). Similarly, A. niger and Penicillium sp. were isolated among the fungus. Hakeem and Bhatnagar (2010) argued that these organisms are widespread in nature and have been associated with industrial wastewater.

Although the four isolates showed the ability to tolerate and reduce lead from textile tannery effluent (Table1), the 2 bacteria performed better than the 2 fungi. Verma et al. (2009 reported that Bacillus species shows differences in resistance and removal of heavy metals such as lead, which may be due to the presence or absence of a metal ion transporter of a particular specificity in the bacterial species and the physiology of the cell. This is similar to how some microorganisms exhibit resistance to antimicrobial agents, which may be related to the process of their survival and their environmental adaptation. The two fungi however, were able to utilize the chromium better than the bacteria. Santhi and Guru (2014) stated that exposure of Aspergillus sp. to toxic heavy metals might have led to physiological adaptation and increased metal tolerance ability, which led to an increased metal biosorption capacity. Fungi have the ability to secrete a wide range of extracellular enzymes in their growth environment or growth medium. This may lead to the capability to grow on a wide range of carbon source (Bello et al., 2016). Jayanth et al. (2014) also argued that filamentous fungi are have a high ion exchange capacity within their cell walls. These biding sites have a high covalent affinity towards toxic transition metal ions such as cadmium, lead, chromium and zinc (Akar and Tunali, 2006). Akar and Tunali (2006) also reported that fungi may have affinity for cadmium, lead, chromium, carboxyl, phosphate and hydroxyl groups that are involved in the binding of heavy metals.

When compared to different standards (Table 4 and Table 5), the isolates have a great potentials for the removal of heavy metals in tannery wastes. As stated by Ezzouhri et al. (2009) and Shazai et al. (2013), the variation in the metal tolerance may be due to the presence of one or more strategies of tolerance or resistant 
mechanisms exhibited by microorganisms and the level of resistance depended on the isolate.

\section{Conclusions}

The bacterial isolates (Bacillus subtilis and $B$. megaterium) and fungal isolates (A. niger and Penicillium sp.) reduced the concentration of lead, chromium and cadmium present in the sterile and raw tannery effluent.

\section{Conflict of interest statement}

Authors declare that they have no conflict of interests.

\section{References}

Abioye, O. P.; Adefisanm A. E.; Aransiola, S. A.; Damisa, D. Biosorption of chromium by Bacillus subtilis and Pseudomonas aeruginosa isolated from waste dumpsite. Expert Opinion on Environmental Biology, v. 4, No. 1, p. 1-3, 2015. https://doi.org/10.4172/ 2325-9655.1000112

Akar, T.; Tunali, S. Biosorption characteristic of Aspergillus flavus biomass for removal of $\mathrm{Pb}$ (II) and $\mathrm{Cu}$ (II) ions from an aqueous solution. Bioresource Technology, v. 97, p.1780-1787, 2006. https://doi.org/ 10.1016/j.biortech.2005.09.009

Bello, O. A.; Abubakar, B. Y.; Abdullahi, I. O. Efficiency of Aspergillus niger, Aspergillus flavus and Microsporum nanum to remove heavy metals from refinery effluent. Journal of Advances in Biology and Biotechnology, v. 6, No. 3, p. 1-6, 2016. https://doi.org/ 10.9734/JABB/2016/25751

Bosnic, M.; Buljan, J.; Daniels, R. P. Pollutants in tannery effluents. Vienna: United Nations Industrial Development Organization, 2000. Available from: <https://www.unido.org/ sites/default/files/2009-05/Pollutants_in_ tannery_effluents_0.pdf $>$. Accessed on: Nov. 24, 2017.

Cheesbrough, M. District Laboratory Practice in Tropical Countries. London: Cambridge University Press, 2006. Part 2.

Devi, R.; Arasappan, S.; Kalyanaraman, R.; Narasimhan, B. A study on biosorption potential of Aspergillus sp. of tannery effluent. Advances in Bioscience and
Biotechnology, v. 5, p.853-860, 2011. https://doi.org/10.4236/abb.2014.510100

Deivasgamani, C.; Das, N. Biodegradation of basic violet 3 by Candida krusel isolated from textile waste water. Biodegradation, v. 22, No. 6, p. 1169-1180, 2011.

Do, T.; Shen, J.; Cawood, G.; Jeckins, R. Biotreatment of textile effluent using Pseudomonas spp. immobilized on polymer supports. In: Hardin, I. R.; Akin, D. E.; Wilson, J. S. (Eds.). Advances in biotreatment for textile processing. Georgia: University of Georgia Press, 2002. p. 234-256.

Domsch, K. H.; Gams, W. Fungi in agricultural soils. 1. ed. London: Longman, 1970.

Ezzouhri, L.; Castro, E.; Moya, M.; Espionola, F.; Lairini, K. Heavy metal tolerance of filamentous fungi isolated from polluted sites in Tangier, Morocco. African Journal of Microbiology Research, v. 3, No. 2, p. 35-48, $2009 . \quad$ Available from: <https://www.academicjournals.org/article/ article1380177143_Ezzouhri et al.pdf>. Accessed on: Nov. 24, 2017.

Hakeem, A.S.; Bhatnagar, S. Heavy metal reduction pulp and paper mill effluent by indigenous microbes. Asian Journal of Experimental Biological Sciences, v. 1, p. 201-203, 2010. Available from: <http://www.ajebs.com/vol1-2010/Society of Applied Scienc201-203.pdf>. Accessed on: Nov. 24, 2017.

Holt, J. G;. Krieg, N. R.; Sneath, P. H. A.; Staley, J. T.; Williams, S. T. Bergy's manual of determinative Bacteriology. Maryland: Williams and Wilkins Publishers, 1994.

Jayanthi, M.; Kanchana, D.; Saranraj, P.; Sujitha, D. Bioadsorption of chromium by Penicillium chrysogenum and Aspergillus niger isolated from tannery effluent. International Journal of Microbiological Research, v. 5, No. 1, p. 40-47, 2014.

Konopka, A.; Zakharova, T. Qualification of bacterial lead resistance via activity assays. Journal of Microbiological Methods, v. 37, No. 1, p.17-22, 1999. https://doi.org/ 10.1016/S0167-7012(99)00032-9

León, M.; Yaryura, P. M.; Montecchia, M. S.; Hernández, A. I.; Correa, O. S.; Pucheu, N. L.; Kerber, N. L.; García, A. F. Antifungal activity of selected indigenous Pseudomonas and Bacillus from soyabean rhizosphere. International Journal of Microbiology, 
v. 2009, Article ID 572049, p. 1-9, 2009. http://dx.doi.org/10.1155/2009/572049

Maier, J.; Kandelbauer, A.; Erlacher, A.; Cavaco-Paulo, A.; Gubits, G. M. A new alkalithermostable azoreductase from Bacillus sp. strain SF. Applied Environmental Microbiology, v. 70, p. 837-844, 2004. https://doi.org/10.1128/AEM.70.2.837844.2004

Malarkodi, $\quad$ M.; $\quad$ Krishnasamy, R.; Kumaraperumal, R.; Chitdeshwari, T. Characterization of heavy metal contaminated soils of Coimbatore district in Tamil Nadu. Journal of Agronomy, v. 6, No. 1, p.147-151, 2007. https://doi.org/10.3923/ja.2007.147.151

Meenambigai, P.; Vijayaraghavan, R.; Shyamala, G. R.; Rajarajeswari, P.; Prabhavathi, P. Biodegradation of heavy metals: a review. International Journal Current Microbiology Applied Science, v. 5, No. 4, p. 375-383, 2016. https://doi.org/ 10.20546/ijcmas.2016.504.045

Mustafa, S.; Ahmed, T.; Naum, A.; Shah, K. H.; Wassum, M. Kinetics of chromium ion removal from tannery wastes using Amberliti IRA-400 $\mathrm{Cl}^{-}$and its hybrids. Water, Air, Soil, \& Pollution, v. 210, No. 1/4, p. 43-50, 2010. https://doi.org/10.1007/s11270-009-02217

Noorjahan, C. Physicochemical characteristics, identification of fungi and biodegradation of industrial effluent. Journal of Environment and Earth Science, v. 4, No. 4, p.32-39, 2014. Available from: <http://www.iiste.org/Journals/index.php/J EES/article/view/11189>. Accessed on: Nov. 24, 2017.

Olukanni, O. D.; Osuntoki, A. A.; Gbenle, G. O. Textile effluent biodegradation potentials of textile effluent-adapted and non-adapted bacteria. African Journal of Biotechnology, v. 5 , No. 20, p. 1980-1984, 2006. Available from: <https://www.ajol.info/index.php/ ajb/article/view/55924/44381>. Accessed on: Nov. 24, 2017.

Rabah, A. B.; Ibrahim, M. L. Physicochemical and microbiological characterization of soils laden with tannery effluents in Sokoto, Nigeria. Nigerian Journal of Basic and
Applied Science, v. 18, No. 1, p. 65-71, 2010. Available from: <https://www.ajol.info/ index.php/njbas/article/download/56843/4 5257>. Accessed on: Nov. 24, 2017.

Salman, H. A.; Ibrahim, M. I.; Tarek, M. M.; Abbas, H.S. Biosorption of heavy metals: a review. Journal of Chemical Science and Technology, v. 3, No.4, p.74-102, 2014. Available from: <http://www.academicpub. org/jcst/paperInfo.aspx?paperid=15568>. Accessed on: Nov. 24, 2017.

Santhi, R.; Guru, V. Biosorption of hexavalent chromium using Aspergillus niger dead biomass and its optimization studies. International Journal of Current Microbiology and Applied Science, v. 3, No. 10, p.669-678, 2014. Available from: <https://www.ijcmas.com/vol-3-10/R.Santhi and V.Guru.pdf>. Accessed on: Nov. 24, 2017.

Srinivas, G.; Boominathan; Estari, M. Studies of efficiency of immobilised bacteria in tannery effluent treatment. Journal of Biology Innovation, v. 2, No. 2, p. 33-42, 2013. Available from: <http://www.jbino. com/docs/Issue02_01_2013.pdf>. Accessed on: Nov. 24, 2017.

Shazia, I.; Kousar, P.; Naila, S.; Kanwal, W.; Ijaz, A.; Iftikhar, A. Tolerance potential of different species of Aspergillus as bioremediation tool. Comparative analysis. E3 Journal of Microbiology Research, v. 1, No. 1, p.1-8, 2013. Available from: <http://www.e3journals.org/cms/articles/1 370128768_ejmbr-12-13 galley proof_gagz1.pdf>. Accessed on: Nov. 24, 2017.

Shivakumar, C. K.; Thippeswamy, B. Effect of fungal biosorbed and nonbiosorbed copper and zinc metal solution on growth and metal uptake of leguminous plans. Research Journal, v. 2, No. 2, p. 6-12, 2012. Available from: <http://updatepublishing.com/ journal/index.php/imrj/article/download/1 547/1531>. Accessed on: Nov. 24, 2017.

Verma, T.; Garg, S. K.; Ramteke, P. W. Genetic correlation between chromium resistance and reduction in Bacillus brevis isolated from tannery effluent. Journal of Applied Microbiology, v. 107, No. 5, p. 1425-1432, $2009 . \quad$ https://doi.org/10.1111/j.13652672.2009.04326.x

License information: This is an open-access article distributed under the terms of the Creative Commons Attribution License, which permits unrestricted use, distribution, and reproduction in any medium, provided the original work is properly cited. 